\title{
The 100th Anniversary Hallym Seminar in Hearing
}

\author{
Hyung-Jong Kim', Junghak Lee ${ }^{2}$ \\ ${ }^{1}$ Department of Otorhinolaryngology-Head and Neck Surgery, Hallym University College of Medicine, Chuncheon, Korea \\ ${ }^{2}$ Institute of Audiology, Department of Audiology, Hallym University of Graduate Studies, Seoul, Korea
}

한림청각학세미나 100 회 기념 논문집을 발간하며

김 형 종'이 정 학

한림대학교 의과대학 이비인후학교실 ${ }^{1}$ 한림국제대학원대학교 청각학과 ${ }^{2}$

지난 2003년 10월 한림대 청각학부 이정학 교수의 강의 Recent advances in audiology 로 시작된 한림청각학세미나는 어 느덧 13년의 세월과 99 번째의 모임을 마치고, 이제 100번째 모 임을 가지게 되었습니다. 잘 아시다시피 한림 청각학세미나는 신경이과학, 청각학 및 언어병리학을 접목하여 이 분야에서 종 사하고 있는 전문가들을 교육하고, 연구의욕을 고취하기 위해 시작되어 매년 1학기 3, 4, 5, 6월, 2학기 9,10,11, 12월 총 8회 씩 최신 지견 및 관심 분야의 지식을 정리하는 강의를 계속 이 어왔습니다. 앞선 99 회의 세미나는 2 번 이상 강의해주신 14 분 포함하여 총 72 분이 강의를 맡아 주셨고, 세미나의 토픽은 41 이과학 주제, 39 청각학 주제, 그리고 19 기타 주제를 번갈아 가며 단 한번의 쉬는 일 없이 지속하여 왔습니다. 이 모임을 통 해 이비인후과 의사들과 언어, 청각학부 전문가들이 긴밀하게 교류함으로써 우리나라 청각학 분야의 발전에 밑거름이 되어 왔다고 자부하고 있습니다.

오늘 100 번째 모임을 준비하면서 저희는 지난 역사를 정리함 과 동시에, 청각학의 현재를 보여주고 앞으로 나아갈 방향을 가늠해볼 수 있는 종설논문집을 준비하여 여기 내어놓게 되었
습니다. 이 논문집에는 그동안 저희 세미나에 참여해주신 분들 을 중심으로 이과학과 청각학분야에서 활발한 활동을 하고 계 신 국내외의 13 분께서 참여해주셨습니다. 청각 기초연구와 검 사법 표준화에 관해 이승환, 이정학 두 분 교수님들께서 원고 를 주셨고, 다양한 청각/어지럼질환과 재활법에 대해 김리석, 정종우, 김규상, 최인용, 박수경, 조양선, 김형종, 박시내, 김진숙, 오수희, 배미란 교수님께서 귀중한 글을 보내주셨습니다.

이 논문집이 순수과학이면서 실용학문이며, 임상의학적 가 치를 가지는 청각학 분야를 모두 보여줄 수는 없습니다. 그러나 이를 통해 현재 각 분야 리더들의 관심분야를 일견하시고, 각자 의 자리에서 청각학을 좀더 발전시키는데 조금이나마 보탬이 되었으면 하는 소망을 가져봅니다. 옥고를 보내주신 모든 저자 분들께 감사드리며, 저희 세미나의 100회를 기념하는 자리에 관심을 가져주신 독자들께도 두루 감사드립니다. 마지막으로 원고 편집에 애써주신 방정화, 이재희, 이효정 교수와 이원진 선생에게 수고의 말씀을 전합니다. 